JEMAP: Jurnal Ekonomi, Manajemen, Akuntansi, dan Perpajakan

ISSN: 2622-612X (Media Online) | Vol.4 | No.1 | April 2021

\title{
PERAN SUPERVISI AKADEMIK SEBAGAI PEMODERASI KOMPETENSI PROFESIONAL, KOMPETENSI PEDAGOGIK DAN KINERJA GURU
}

\author{
THE ROLE OF ACADEMIC SUPERVISION AS A MODERATOR OF \\ PROFESSIONAL COMPETENCY, PEDAGOGIC COMPETENCY \\ AND TEACHER PERFORMANCE
}

\author{
Kuntari $^{1}$, Robertus Basiya ${ }^{2}$, Lie Liana ${ }^{3}$ \\ ${ }^{1}$ kuntarids@gmail.com, ${ }^{2}$ rbasiya@edu.unisbank.ac.id, \\ lieliana@edu.unisbank.ac.id
}

Magister Manajemen Universitas Stikubank Semarang

\begin{abstract}
This research aims to examine the effect of professional competence and pedagogical competence on teacher performance moderated by academic supervision. This type of research is an explanatory research. The population of the study was 149 private high school teachers in Pati District, Pati Regency. The data analysis technique used multiple linear regression analysis. The results showed that professional competence has a positive and significant effect on teacher performance, pedagogical competence doesn't impact on teacher's performance, academic supervision has a positive and significant effect on teacher performance, academic supervision does not moderate the effect of professional competence on teacher performance, academic supervision does not moderate the influence of pedagogical competence on teacher performance.
\end{abstract}

Keywords: professional competence, pedagogic competence, academic supervision, teacher performance.

\begin{abstract}
Abstrak: Penelitian ini bertujuan untuk menguji pengaruh kompetensi profesional dan kompetensi pedagogik terhadap kinerja guru dimoderasi supervisi akademik. Jenis penelitian ini adalah penelitian eksplanatori. Populasi penelitian adalah seluruh guru SMA Swasta se-Kecamatan Pati Kabupaten Pati sebanyak 149 guru. Teknik analisis data menggunakan analisis regresi linier berganda. Hasil penelitian menunjukkan bahwa kompetensi profesional berpengaruh positif dan signifikan terhadap kinerja guru, kompetensi pedagogik tidak berpengaruh terhadap kinerja guru, supervisi akademik berpengaruh positif dan signifikan terhadap kinerja guru, supervisi akademik tidak memoderasi pengaruh kompetensi profesional terhadap kinerja guru, supervisi akademik tidak memoderasi pengaruh kompetensi pedagogik terhadap kinerja guru.
\end{abstract}

Kata kunci: kompetensi profesional, kompetensi pedagogik, supervisi akademik, kinerja guru. 
JEMAP: Jurnal Ekonomi, Manajemen, Akuntansi, dan Perpajakan

ISSN: 2622-612X (Media Online) | Vol.4 | No.1 | April 2021

\section{PENDAHULUAN}

Keberhasilan pendidikan di sekolah sangat dipengaruhi kualitas guru dalam mengajar. Guru memiliki kompetensi yang dapat menentukan kinerja yaitu kompetensi profesional dan kompetensi pedagogik. Kinerja guru yang dipengaruhi oleh kompetensi professional dan kompetensi pedagogik tersebut akan semakin meningkat jika dimoderasi oleh supervisi akademik. Hal ini disebabkan karena dengan supervisi akademik maka kinerja guru menjadi terencana dengan baik, sistematis, dan terstruktur. Di sisi lain ada beberapa kemungkinan yang menyebabkan kinerja guru menjadi menurun seperti faktor kesibukan individu guru, faktor kemalasan, asal datang mengajar (hanya sekedar datang menyampaikan materi), maupun tidak mempunyai indikator pencapaian kompetensi yang ingin dicapai dalam pembelajaran. Maka dengan adanya supervisi akademik akan dapat memperkuat kompetensi profesional dan kompetensi pedagogik guru sehingga dapat meningkattkan kinerja guru.

Keterkaitan antara kemampuan guru dengan hasil proses belajar mengajar di 6 SMA Swasta se-Kecamatan Pati menunjukkan rata-rata nilai kelulusan selama 3 tahun mulai tahun pelajaran 2016/2017, 2017/2018, dan 2018/2019, masih dalam klasifikasi C dan D. Sedangkan guru yang sudah mendapatkan sertifikasi dan mendapat tunjangan profesi sebesar $81,2 \%$. Hal ini menunjukkan bahwa kinerja guru masih rendah dan sertifikasi guru belum mampu mendorong peningkatan kinerja guru. Maka dari itu supaya guru mempunyai kinerja yang semakin baik diperlukan adanya supervisi akademik dan peningkatan kompetensi baik kompetensi professional dan kompetensi pedagogic.

Andronache (2016), Dewi (2015), Hasan (2017), Sappaile (2017), Hakim (2015), Paida (2018), Sopandi (2019), dan Nurdianti (2017) dalam penelitiannya menyatakan bahwa kompetensi profesional berpengaruh signifikan terhadap kinerja guru; sedangkan Yusnita (2018) menyatakan kompetensi profesional mempunyai korelasi yang negatif terhadap kinerja guru, Hidayat (2012), dan Yusriadi (2014) menyatakan kompetensi profesional tidak berpengaruh terhadap kinerja guru. 
JEMAP: Jurnal Ekonomi, Manajemen, Akuntansi, dan Perpajakan

ISSN: 2622-612X (Media Online) | Vol.4 | No.1 | April 2021

Rahman (2014), Mulyadi (2011), Novebri dkk. (2018), Sappaile (2017), Nurdianti (2017), Paida (2018), Heriswanto (2018), dan Poro dkk. (2018), dalam penelitiannya menyatakan adanya pengaruh yang positif dan signifikan antara kemampuan pedagogik terhadap kinerja guru. Sedangkan penelitian Sumual dkk. (2017) dan Yusnita dkk. (2018) menyatakan adanya pengaruh negatif antara kompetensi pedagogik terhadap kinerja guru.

Aldaihani (2017), Veloo (2014), Ramadhan (2017). Barinto (2012), Hafni (2020), dan Purbasari (2015), menyatakan adanya pengaruh positif dan signifikan antara supervisi akademik terhadap kinerja. Sedangkan penelitian Tesema (2014), Ndapaloka (2016), dan Ndebele (2013) menyatakan bahwa supervisi akademik tidak berpengaruh terhadap kinerja guru.

Berdasarkan fenomena dan hasil penelitian para peneliti terdahulu dirumuskan tujuan penelitian yaitu untuk menganalisis dan mengetahui pengaruh supervisi akademik sebagai variable pemoderasi kompetensi profesional dan kompetensi pedagogik terhadap kinerja guru di 6 sekolah SMA swasta seKecamatan Pati.

\section{KERANGKA TEORITIS}

\section{Kompetensi Profesional}

Ikhrom (2018) menyatakan karakteristik guru kompeten yaitu melakukan proses mengajar, menetapkan tujuan mengajar, mengawasi dan mengelola materi pelajaran, memahami prinsip-prinsip pelajaran, dan memiliki keinginan untuk terus berkembang.

Guru profesional adalah guru yang mempunyai pengetahuan tentang apa yang dilakukan siswa di kelas setiap saat dan juga peduli tentang apa yang mereka lakukan. Ciri-ciri pribadi guru yang profesional antara lain empati dengan siswa, menghormati individu, memiliki pandangan dan sikap positif, memiliki kemampuan melakukan pendekatan, dan rasa humor (Arifin, 2013).

Permendiknas No.16 Tahun 2007 menyatakan bahwa kompetensi profesional merupakan kemampuan penguasaan materi pembelajaran secara luas dan mendalam sesuai dengan standar kompetensi yang ditetapkan dalam Standar 
Nasional Pendidikan yaitu penguasaan terhadap materi, struktur, konsep, dan pola pikir , penguasaan standar kompetensi dan kompetensi dasar mata pelajaran , pengembangan materi pembelajaran, pengembangan keprofesionalan secara berkelanjutan dengan melakukan tindakan reflektif, dan pemanfaatan teknologi informasi dan komunikasi untuk mengembangkan diri.

\section{Kompetensi Pedagogik}

Kompetensi pedagogik adalah kemampuan memahami wawasan dasar pendidikan, pemahaman peserta didik, mengembangkan kurikulum/ silabus, mendesain pembelajaran, mengimplementasikan pendidikan dan pembelajaran dialogis, melakukan evaluasi, dan mengembangkan aktualisasi potensi peserta didik (Muyiman, 2018).

Sedangkan menurut Syahruddin dkk. (2013) menyebutkan bahwa kompetensi pedagogik mengacu pada kinerja, pengetahuan dan keterampilan dalam pengajaran dan pembelajaran sehingga mencakup kemampuan guru untuk mengelola proses belajar mengajar dari perencanaan hingga tahap evaluasi.

Pengetahuan pedagogis guru dan profesi guru, berupa pengetahuan, keterampilan dan keahlian yang dibutuhkan oleh para praktisi profesi penuh adalah hasil dari periode panjang pelatihan khusus dan pengembangan profesional berkelanjutan (Guerriero, 2017).

\section{Supervisi Akademik}

Supervisi merupakan persyaratan penting dalam manajemen pendidikan yang berkaitan dengan taktik manajemen sumber daya manusia dan material yang efisien dan efektif yang merupakan cara untuk memberi nasihat, membimbing, menyegarkan, mendorong, merangsang, meningkatkan dan mengawasi guru dengan harapan mencari kerja sama mereka agar mereka dapat berhasil dalam tugas mengajar dan manajemen kelas (Kotirdea \& Yunos, 2014).

Menurut Glickman (1981) mengemukakan bahwa supervisi yang baik harus mampu membuat guru semakin kompeten yaitu guru semakin menguasai kompetensi baik kompetensi pedagogik, kepribadian, sosial, maupun profesional. Tujuannya adalah membantu guru mengembangkan kemampuan profesional, 
JEMAP: Jurnal Ekonomi, Manajemen, Akuntansi, dan Perpajakan

ISSN: 2622-612X (Media Online) | Vol.4 | No.1 | April 2021

meningkatkan kualitas pembelajaran, dan mendorong guru untuk menggunakan semua kemampuan mereka dalam melaksanakan pembelajaran. Selain tujuan tersebut, peran supervisi akademik mencakup sepuluh hal yaitu clarifying (mengidentifikasi masalah, listening (mendengarkan), reflecting (merefleksikan), presenting (menyajikan), clarifying (klarifikasi), problem solving (pemecahan masalah, encouraging (mendorong/menguatkan), negotiating (negosiasi), standardizing (standarisasi), dan reflecting (refleksi) (Glickman et al., 2014).

\section{Kinerja Guru}

Kinerja berkaitan dengan tugas dan tanggungjawab. Mangkunegara (2009) menyatakan bahwa kinerja merupakan hasil kerja secara kualitas dan kuantitas yang dicapai oleh seseorang karyawan dalam melaksanakan tugasnya sesuai dengan tanggung jawab yang diberikan kepadanya. Menurut Permendiknas Nomor 41 Tahun 2007, kinerja guru adalah prestasi mengajar guru dalam tugas pokok dan fungsinya tenaga profesional tenaga pendidikan yang dapat dilihat dari unjuk kerja, hasil kerja, prestasi sebagai bentuk tanggungjawab atas pekerjaan yang diembannya.

Mulyasa (2011) menyatakan bahwa sedikitnya ada sepuluh faktor yang dapat meningkatkan kinerja guru antara lain yaitu dorongan untuk bekerja, tanggungjawab terhadap tugas, minat terhadap tugas, penghargaan terhadap tugas, peluang untuk berkembang, perhatian terhadap sekolah, hubungan interpersonal dengan sesama guru, MGMP dan KKG, kelompok diskusi terbimbing, dan layanan perpustakaan.

Berbagai kajian teori tersebut didukung dari hasil penelitian Basiya \& Hakim (2018) didapatkan hasil bahwa supervisi akademik memoderasi (memperkuat) pengaruh kompetensi profesional terhadap kinerja guru. Kemudian berdasarkan hasil penelitian Liana \& Suwarto (2014) diperoleh hasil bahwa supervisi akademik memoderasi kompetensi pedagogik terhadap kinerja guru.

\section{HIPOTESIS PENELITIAN}

Guru yang profesional adalah guru yang kualifikasi unggul yang dapat dibuktikan dengan siswa-siswanya mampu meraih prestasi signifikan (Ikhrom, 
JEMAP: Jurnal Ekonomi, Manajemen, Akuntansi, dan Perpajakan

ISSN: 2622-612X (Media Online) | Vol.4 | No.1 | April 2021

2018). Andronache (2016), Dewi (2015), Hasan (2017), Sappaile (2017), Hakim (2015), Paida (2018), Sopandi (2019), dan Nurdianti (2017) dalam penelitiannya menyatakan bahwa kompetensi profesional berpengaruh signifikan terhadap kinerja guru menyimpulkan kompetensi profesional berpengaruh positif terhadap kinerja guru. Berdasarkan penelitian tersebut dirumuskan hipotesis pertama:

\section{H1: Kompetensi profesional berpengaruh positif dan signifikan terhadap}

\section{kinerja guru.}

Pengetahuan pedagogis guru dan profesi guru berupa pengetahuan, keterampilan dan keahlian pengembangan profesional berkelanjutan (Guerriero, 2017). Rahman (2014), Mulyadi (2011), Novebri dkk. (2018), Sappaile (2017), Nurdianti (2017), Paida (2018), Heriswanto (2018), dan Poro dkk. (2018), dalam penelitiannya menyatakan adanya pengaruh yang positif dan sifnifikan antara kemampuan pedagogik terhadap kinerja guru. Berdasarkan penelitian tersebut dirumuskan hipotesis kedua:

H2: Kompetensi pedagogik berpengaruh positif dan signifikan terhadap kinerja guru

Guru mempunyai kesempatan yang luas untuk pertumbuhan dan pengembangan profesional dan pengawasan telah menjadi bagian penting dari profesi guru (Aldaihani, 2017). Veloo (2014), Ramadhan (2017), Barinto (2012), Hafni (2020), dan Purbasari (2015), menyatakan adanya pengaruh positif dan signifikan antara supervisi akademik terhadap kinerja. Berdasarkan penelitian tersebut dirumuskan hipotesis ketiga:

H3: Supervisi akademik berpengaruh positif dan signifikan terhadap kinerja guru

Supervisi akademik secara teoritis akan mempengaruhi kompetensi profesional terhadap kinerja guru. Hal ini sesuai dengan penelitian Basiya \& Hakim (2018) yang menyimpulkan supervisi akademik yang baik akan memoderasi yaitu memperkuat pengaruh kompetensi profesional terhadap kinerja guru. Berdasarkan penelitian tersebut dirumuskan hipotesis keempat:

H4: Supervisi akademik memoderasi pengaruh kompetensi profesional terhadap kinerja guru 
JEMAP: Jurnal Ekonomi, Manajemen, Akuntansi, dan Perpajakan

ISSN: 2622-612X (Media Online) | Vol.4 | No.1 | April 2021

Supervisi yang dilakukan oleh Kepala Sekolah yang efektif akan sangat membantu mengetahui kemampuan dan kompetensi guru dalam mengelola pembelajaran. Hal ini sesuai dengan penelitian Liana dan Suwarto (2014) yang menyimpulkan supervisi akademik memoderasi kompetensi pedagogik terhadap kinerja guru. Berdasarkan penelitian tersebut maka hipotesis kelima:

\section{H5: Supervisi akademik memoderasi pengaruh kompetensi pedagogik terhadap kinerja guru.}

\section{KERANGKA KONSEPTUAL}

Penelitian ini menggunakan. quasi moderator dimana variabel yang berfungsi dua hal, yaitu variabel moderasi berpengaruh langsung terhadap variabel dependen (criterion), dan variabel yang berfungsi memoderasi pengaruh variabel independen (predictor) terhadap variabel dependen.

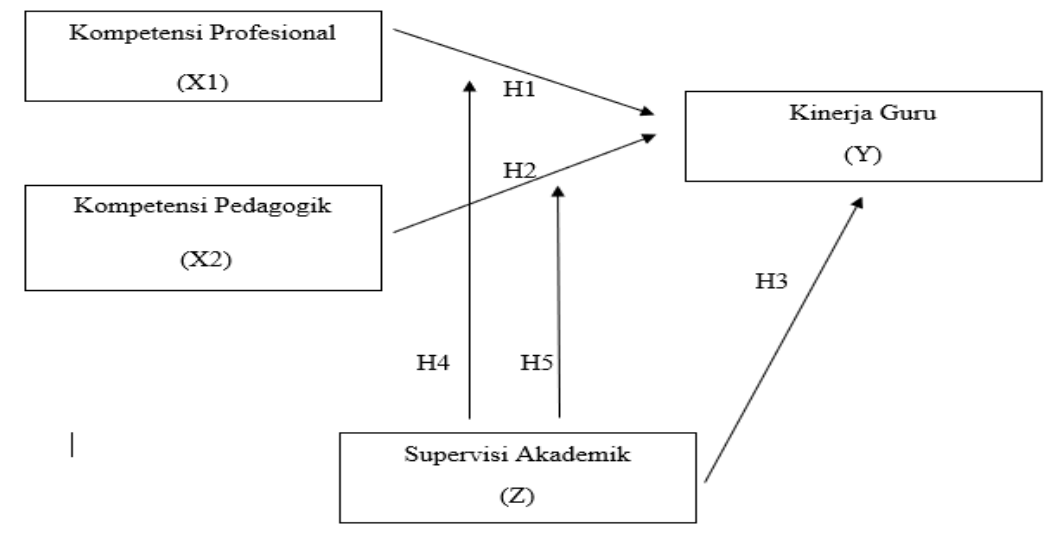

Gambar 1: Kerangka Konseptual Penelitian

\section{METODE PENELITIAN}

Sumber data penelitian ini adalah data primer dimana pengumpulan data menggunakan kuesioner dengan Skala Likert. Rentang jawaban menggunakan skala 1 sampai dengan 5 yaitu sangat tidak setuju (bobot 1), tidak setuju (bobot 2), netral (bobot 3), setuju (bobot 4) dan sangat setuju (bobot 5). Kuesioner berisi tentang pernyataan kompetensi profesional, kompetensi pedagogik, supervisi akademik, dan kinerja guru. Instrumen kompetensi professional dan kompetensi 
JEMAP: Jurnal Ekonomi, Manajemen, Akuntansi, dan Perpajakan

ISSN: 2622-612X (Media Online) | Vol.4 | No.1 | April 2021

pedagogic dari Permendiknas No. 16 Tahun 2007. Instrumen kinerja guru dari Permendiknas No 41 Tahun 2007. Instrumen supervisi akademik dikembangkan dari lembar observasi kemampuan mengajar pusat Pendidikan dan pelatihan pegawai Departemen Pendidikan dan Kebudayaan RI Tahun 2009. Teknik sampling yang digunakan adalah sampling jenuh. Sampling Jenuh adalah teknik penentuan sampel dimana semua anggota dari populasi digunakan sebagai sampel (Sugiyono, 2011).

Jenis populasi penelitian adalah populasi terbatas yang berjumlah 149 guru dari 6 SMA Swasta se-Kecamatan Pati, yaitu SMA PGRI 1 Pati, SMA Muhammadiyah 1 Pati, SMA Nasional Pati, SMA Yos Sudarso Pati, SMA BOPKRI 1 Pati, dan SMA Wahid Hasyim Pati.

Teknik analisis data yang digunakan untuk menganalisis pengaruh variabel independen terhadap variabel dependen menggunakan analisis regresi linier berganda. Pengujian pengaruh variabel moderasi menggunakan teknik quasi moderasi selisih mutlak.

\section{HASIL PENELITIAN}

\section{Analisis Deskriptif}

Responden dalam penelitian ini sebagian besar adalah perempuan sebanyak 85 orang dengan tingkat pendidikan terakhir sarjana sebanyak 141 orang, dengan usia 36 tahun s.d 45 tahun sebanyak 48 orang, masa kerja 11 tahun s.d. 15 tahun, dan sebagian besar sudah memperoleh sertifikasi guru sebesar 117 orang, serta telah mendapat pelatihan guru yang diselenggarakan sekolah minimal sebanyak 3 kali.

Variabel kompetensi profesional memiliki mean sebesar 4,415 yang berarti kompetensi profesional yang dimiliki para guru pada tingkat yang tinggi. Variabel kompetensi pedagogik mempunyai mean sebesar 4,421 yang berarti kompetensi pedagogik para guru tergolong tinggi. Variabel supervisi akaemik memiliki mean sebesar 4,394 yang berarti supervisi akademik yang dilakukan oleh pimpinan tergolong tinggi, dan variabel kinerja guru memiliki mean sebesar 4,384 yang berarti tingkat kinerja para guru juga tergolong tinggi. 
JEMAP: Jurnal Ekonomi, Manajemen, Akuntansi, dan Perpajakan

ISSN: 2622-612X (Media Online) | Vol.4 | No.1 | April 2021

\section{Uji Instrumen Penelitian}

\section{Uji Validitas}

Uji validitas dilakukan dengan menggunakan Confirmatory Factor Analysis (CFA). Hasil uji validitas variabel kompetensi profesional, kompetensi pedagogik, supervisi akademik, dan kinerja guru, semuanya memiliki nilai KMO>0,5. Hal ini menunjukkan bahwa kecukupan sampel terpenuhi. Sedangkan nilai loading factor pada semua indikator variabel kompetensi profesional $\left(\mathrm{X}_{1}\right)$, kompetensi pedagogik $\left(\mathrm{X}_{2}\right)$, supervisi akademik $(\mathrm{Z})$, dan kinerja guru $(\mathrm{Y})>0,4$. Dengan demikian semua indikator tersebut valid.

Berikut table uji validitas dan reliabilitas:

Tabel 1

Hasil Uji Validitas Variabel Kompetensi Profesional ( $\left.\mathbf{X}_{1}\right)$

\begin{tabular}{|c|c|c|c|c|c|}
\hline Variabel & KMO & Sig. & Indikator & $\begin{array}{l}\text { Load- } \\
\text { factor }\end{array}$ & Keterangan \\
\hline Kompetensi & 0,740 & 0,000 & $\mathrm{X}_{1.1}$ & 0,859 & Valid \\
\hline \multirow{4}{*}{$\begin{array}{l}\text { Profesional } \\
\qquad\left(\mathrm{X}_{1}\right)\end{array}$} & & & $\mathrm{X}_{1.2}$ & 0,916 & Valid \\
\hline & & & $\mathrm{X}_{1.3}$ & 0,870 & Valid \\
\hline & & & $\mathrm{X}_{1.4}$ & 0,735 & Valid \\
\hline & & & $\mathrm{X}_{1.5}$ & 0,894 & Valid \\
\hline
\end{tabular}

Tabel 2

Hasil Uji Validitas Variabel Kompetensi Pedagogik $\left(\mathbf{X}_{2}\right)$

\begin{tabular}{cccccc}
\hline Variabel & KMO & Sig. & Indikator & Load-factor & Keterangan \\
\hline Kompetensi & 0,807 & 0,000 & $\mathrm{X}_{2.1}$ & 0,637 & Valid \\
\cline { 3 - 5 } Pedagogik $\left(\mathrm{X}_{2}\right)$ & & & $\mathrm{X}_{2.2}$ & 0,532 & Valid \\
\cline { 3 - 5 } & & & $\mathrm{X}_{2.3}$ & 0,855 & Valid \\
\cline { 3 - 5 } & & $\mathrm{X}_{2.4}$ & 0,761 & Valid \\
\cline { 3 - 5 } & & $\mathrm{X}_{2.5}$ & 0,879 & Valid \\
\cline { 3 - 5 } & & $\mathrm{X}_{2.6}$ & 0,762 & Valid \\
\cline { 3 - 5 } & & $\mathrm{X}_{2.7}$ & 0,706 & Valid
\end{tabular}


JEMAP: Jurnal Ekonomi, Manajemen, Akuntansi, dan Perpajakan

ISSN: 2622-612X (Media Online) | Vol.4 | No.1 | April 2021

\begin{tabular}{|c|c|c|c|c|}
\hline Variabel & KMO Sig. & Indikator & Load-factor & Keterangan \\
\hline & & $\mathrm{X}_{2.8}$ & 0,714 & Valid \\
\hline & & $\mathrm{X}_{2.9}$ & 0,604 & Valid \\
\hline & & $\mathrm{X}_{2.10}$ & 0,602 & Valid \\
\hline
\end{tabular}

Tabel 3

Hasil Uji Validitas Variabel Supervisi Akademik (Z)

\begin{tabular}{|c|c|c|c|c|c|}
\hline Variabel & $\mathrm{KMO}$ & Sig. & Indikator & Load-factor & Keterangan \\
\hline Supervisi & 0,820 & 0,000 & Z.1 & 0,828 & Valid \\
\hline Akademik & & & Z.2 & 0,638 & Valid \\
\hline \multirow[t]{7}{*}{$(Z)$} & & & Z.3 & 0,817 & Valid \\
\hline & & & Z.4 & 0,798 & Valid \\
\hline & & & Z.5 & 0,777 & Valid \\
\hline & & & Z.6 & 0,779 & Valid \\
\hline & & & Z.7 & 0,604 & Valid \\
\hline & & & Z.8 & 0,796 & Valid \\
\hline & & & Z.9 & 0,748 & Valid \\
\hline
\end{tabular}

Tabel 4

Hasil Uji Validitas Variabel Kinerja Guru (Y)

\begin{tabular}{|c|c|c|c|c|c|}
\hline Variabel & KMO & Sig. & Indikator & $\begin{array}{l}\text { Load- } \\
\text { factor }\end{array}$ & Keterangan \\
\hline Kinerja & 0,766 & 0,000 & Y.1 & 0,766 & Valid \\
\hline \multirow[t]{7}{*}{ Guru (Y) } & & & Y.2 & 0,804 & Valid \\
\hline & & & Y.3 & 0,841 & Valid \\
\hline & & & Y.4 & 0,722 & Valid \\
\hline & & & Y.5 & 0,743 & Valid \\
\hline & & & Y.6 & 0,701 & Valid \\
\hline & & & Y.7 & 0,559 & Valid \\
\hline & & & Y.8 & 0,705 & Valid \\
\hline
\end{tabular}


JEMAP: Jurnal Ekonomi, Manajemen, Akuntansi, dan Perpajakan

ISSN: 2622-612X (Media Online) | Vol.4 | No.1 | April 2021

\begin{tabular}{|c|c|c|c|c|}
\hline Variabel & KMO Sig. & Indikator & $\begin{array}{l}\text { Load- } \\
\text { factor }\end{array}$ & Keterangan \\
\hline & & Y.9 & 0,814 & Valid \\
\hline & & Y.10 & 0,800 & Valid \\
\hline & & Y.11 & 0,611 & Valid \\
\hline
\end{tabular}

\section{Uji Reliabilitas}

Hasil uji reliabilitas variabel kompetensi profesional, kompetensi pedagogik, supervisi akademik, dan kinerja guru, memperoleh nilai Cronbach's Aplha $>0,7$. Hal ini menunjukkan bahwa keempat variabel tersebut reliabel sehingga dapat dilakukan analisis selanjutnya.

Tabel 5. Hasil Uji Reliabilitas

\begin{tabular}{|c|c|c|c|c|}
\hline \multirow[b]{2}{*}{ Variabel } & \multirow[b]{2}{*}{$\begin{array}{c}\text { Cronbach Alpha } \\
\text { Variabel }\end{array}$} & \multicolumn{3}{|c|}{ Cronbach } \\
\hline & & Indikator & $\begin{array}{c}\text { Alpha } \\
\text { Indikator }\end{array}$ & Keterangan \\
\hline Kompetensi & 0,908 & $\mathrm{X}_{1.1}$ & 0,886 & Reliabel \\
\hline \multirow{4}{*}{$\begin{array}{l}\text { Profesional } \\
\qquad\left(\mathrm{X}_{1}\right)\end{array}$} & & $\mathrm{X}_{1.2}$ & 0,871 & Reliabel \\
\hline & & $\mathrm{X}_{1.3}$ & 0,885 & Reliabel \\
\hline & & $\mathrm{X}_{1.4}$ & 0,918 & Reliabel \\
\hline & & $\mathrm{X}_{1.5}$ & 0,877 & Reliabel \\
\hline Kompetensi & 0,889 & $\mathrm{X}_{2.1}$ & 0,878 & Reliabel \\
\hline \multirow{10}{*}{$\begin{array}{c}\text { Pedagogik } \\
\left(\mathrm{X}_{2}\right)\end{array}$} & & $\mathrm{X}_{2.2}$ & 0,886 & Reliabel \\
\hline & & $\mathrm{X}_{2.3}$ & 0,870 & Reliabel \\
\hline & & $\mathrm{X}_{2.4}$ & 0,879 & Reliabel \\
\hline & & $\mathrm{X}_{2.5}$ & 0,867 & Reliabel \\
\hline & & $\mathrm{X}_{2.6}$ & 0,879 & Reliabel \\
\hline & & $\mathrm{X}_{2.7}$ & 0,882 & Reliabel \\
\hline & & $\mathrm{X}_{2.8}$ & 0,880 & Reliabel \\
\hline & & $\mathrm{X}_{2.9}$ & 0,881 & Reliabel \\
\hline & & $\mathrm{X}_{2.10}$ & 0,881 & Reliabel \\
\hline & 0,905 & Z.1 & 0,889 & Reliabel \\
\hline
\end{tabular}


JEMAP: Jurnal Ekonomi, Manajemen, Akuntansi, dan Perpajakan

ISSN: 2622-612X (Media Online) | Vol.4 | No.1 | April 2021

\begin{tabular}{|c|c|c|c|c|}
\hline \multirow{3}{*}{ Variabel } & \multirow{3}{*}{$\begin{array}{c}\text { Cronbach Alpha } \\
\text { Variabel }\end{array}$} & \multicolumn{3}{|c|}{ Cronbach } \\
\hline & & Indikator & Alpha & Keterangan \\
\hline & & & Indikator & \\
\hline Supervisi & & Z.2 & 0,905 & Reliabel \\
\hline \multirow{7}{*}{$\begin{array}{l}\text { Akademik } \\
\text { (Z) }\end{array}$} & & Z.3 & 0,890 & Reliabel \\
\hline & & $\mathrm{Z} .4$ & 0,892 & Reliabel \\
\hline & & Z.5 & 0,892 & Reliabel \\
\hline & & Z.6 & 0,891 & Reliabel \\
\hline & & Z.7 & 0,905 & Reliabel \\
\hline & & Z.8 & 0,890 & Reliabel \\
\hline & & Z.9 & 0,895 & Reliabel \\
\hline \multirow{11}{*}{$\begin{array}{l}\text { Kinerja Guru } \\
\text { (Y) }\end{array}$} & \multirow[t]{11}{*}{0,912} & Y.1 & 0,905 & Reliabel \\
\hline & & Y.2 & 0,899 & Reliabel \\
\hline & & Y.3 & 0,898 & Reliabel \\
\hline & & Y.4 & 0,905 & Reliabel \\
\hline & & Y.5 & 0,903 & Reliabel \\
\hline & & Y.6 & 0,905 & Reliabel \\
\hline & & Y.7 & 0,913 & Reliabel \\
\hline & & Y.8 & 0,906 & Reliabel \\
\hline & & Y.9 & 0,899 & Reliabel \\
\hline & & Y.10 & 0,899 & Reliabel \\
\hline & & Y.11 & 0,910 & Reliabel \\
\hline
\end{tabular}

\section{Uji Asumsi Klasik}

\section{Uji Normalitas}

Hasil uji normalitas memperoleh nilai asymp. sig=0,779, nilai ini lebih besar dari 0,05 sehingga dapat disimpulkan bahwa data residual terdistribusi normal.

\section{Uji Heteroskedastisitas}

Uji heteroskedastisitas dengan menggunakan uji Glejser menunjukkan seluruh variabel independen yaitu variabel kompetensi profesional, variabel 
JEMAP: Jurnal Ekonomi, Manajemen, Akuntansi, dan Perpajakan

ISSN: 2622-612X (Media Online) | Vol.4 | No.1 | April 2021

kompetensi pedagogik, dan variabel supervisi akademik, diperoleh nilak signifikanso lebih besar 0,05 , sehingga dapat dinyatakan bebas dari masalah heteroskedastisitas.

\section{Analisis Regresi Linier Berganda}

\section{Uji Fit Model}

Hasil uji F diperoleh nilai sig.0,000<0,05 yang menunjukkan bahwa semua variabel independent kompetensi profesional, kompetensi pedagogik, supervisi akademik, moderasi 1, dan moderasi 2 berpengaruh secara simultan terhadap variabel dependent kinerja guru. Hal ini berarti model memenuhi goodness of fit.

Hasil Uji R ${ }^{2}$ diperoleh nilai Adjusted R-Square sebesar 0,850 (85\%), artinya variasi dari semua variabel kompetensi profesional, kompetensi pedagogik, supervisi akademik, moderasi 1, moderasi 2 mampu menjelaskan variasi variabel kinerja guru sebesar $85 \%$ sedangkan sisanya yaitu $15 \%$ dijelaskan oleh variabel lain di luar model.

\section{Hasil Analisis Regresi Linier Berganda}

Hasil analisis regresi linier berganda dengan teknik quasi moderasi selisih mutlak diperoleh persamaan:

$\mathrm{Y}=0,670 \mathrm{X}_{1}+0,013 \mathrm{X}_{2}+0,338 \mathrm{Z}+0,014\left|\mathrm{X}_{1}-\mathrm{Z}\right|-0,040\left|\mathrm{X}_{2}-\mathrm{Z}\right|$

Keterangan:

$\mathrm{X}_{1}=$ Variabel Kompetensi Profesional

$\mathrm{X}_{2}=$ Variabel Kompetensi Pedagogik

$\mathrm{Z}=$ Supervisi Akademik

$\left|\mathrm{X}_{1}-\mathrm{Z}\right|=$ Moderasi1

$\left|\mathrm{X}_{2}-\mathrm{Z}\right|=$ Moderasi2

$\mathrm{Y}=$ Kinerja Guru

Hasil Uji Hipotesis (Uji T) 
JEMAP: Jurnal Ekonomi, Manajemen, Akuntansi, dan Perpajakan

ISSN: 2622-612X (Media Online) | Vol.4 | No.1 | April 2021

Tabel 1. Tabel Uji Hipotesis

\begin{tabular}{cccc}
\hline Model & Beta & $t$ & Sig. \\
\hline & & & \\
\hline Kompetensi & 0,670 & 10,47 & 0,000 \\
Profesional & & 5 & \\
$(\mathrm{X} 1)$ & & & \\
\hline Kompetensi & 0,013 & 0,233 & 0,816 \\
Pedagogik & & & \\
(X2) & & & \\
\hline Supervisi & 0,338 & 8,444 & 0,000 \\
Akademik & & & \\
$(\mathrm{Z})$ & & & \\
\hline $\mid \mathrm{X} 1$ - Z & 0,014 & 0,348 & 0,729 \\
\hline |X2 - Z & $-0,040$ & $-0,967$ & 0,335 \\
\hline Variabel Dependen: Kinerja Guru (Y) \\
Sumber: Hasil Uji Hipotesis
\end{tabular}

Berdasarkan Tabel 1 tersebut diperoleh nilai $\mathrm{t}$ dan koefisien beta yang menunjukkan bahwa variabel kompetensi profesional berpengaruh positif dan signifikan terhadap kinerja guru karena memiliki nilai sig. $0,000<0,05$ dan nilai koefisien beta $=0,670$. Hal ini menunjukkan hipotesis 1 yang menyatakan kompetensi profesional berpengaruh positif terhadap kinerja guru diterima (H1 diterima).

Kompetensi pedagogik tidak berpengaruh terhadap kinerja guru karena mempunyai nilai sig.0,816>0,05. Hal ini menunjukkan hipotesis 2 yang menyatakan kompetensi pedagogik berpengaruh positif dan signifikan terhadap kinerja guru ditolak (H2 ditolak).

Supervisi akademik berpengaruh positif dan signifikan terhadap kinerja guru karena nilai sig.0,000<0,05 dengan nilai koefisien beta sebesar 0,338. Hal ini menunjukkan hipotesis 3 yang menyatakan supervisi akademik berpengaruh positif dan signifikan terhadap kinerja guru diterima (H3 diterima). 
Supervisi akademik tidak memperkuat secara signifikan pengaruh kompetensi profesional terhadap kinerja guru karena mempunyai nilai koefisien beta sebesar 0,014 (sangat kecil) dan nilai sig.0,729>0,05. Tidak memperkuat secara signifikan diartikan tidak memoderasi. Hal ini menujukkan hipotesis 4 yang menyatakan supervisi akademik memoderasi pengaruh kompetensi profesional terhadap kinerja guru ditolak (H4 ditolak).

Supervisi akademik tidak memperlemah secara signifikan pengaruh kompetensi pedagogik terhadap kinerja guru karena mempunyai nilai koefisien beta sebesar -0,040 (sangat kecil) dan nilai sig.0,335>0,05. Tidak memperlemah secara signifikan diartikan tidak memoderasi. Hal ini menunjukkan hipotesis 5 yang menyatakan supervisi akademik memoderasi pengaruh kompetensi pedagogik terhadap kinerja guru ditolak (H5 ditolak).

\section{PEMBAHASAN}

\section{Kompetensi Profesional Berpengaruh Positif Dan Signifikan Terhadap Kinerja Guru}

Pernyataan tersebut mengandung arti semakin tinggi kompetensi profesional semakin tinggi kinerja guru. Hal ini menunjukkan guru telah menguasai materi, struktur, konsep menguasai standar kompetensi, serta mengembangkan keprofesionalannya yang tinggi sehingga dapat meningkatkan kinerjanya. Penyusunan Rencana Pelaksanaan Pembelajaran (RPP) di awal pembelajaran yang selalu dilakukan oleh guru, penyampaian bahan ajar sesuai Kompetensi Dasar (KD) sebelum proses belajar mengajar, evaluasi proses dan hasil pembelajaran, selalu melakukan presensi sebelum kegiatan pembelajaran, serta selalu melakukan evaluasi melalui test tertulis maupun non tertulis merupakan indikator-indikator untuk meningkatkan kompetensi profesonal guru.

Hal tersebut juga didukung adanya guru-guru berprestasi baik ditingkat propinsi maupun nasional; guru-guru yang mampu menghasilkan hasil karya berupa buku-buku, metode pembelajaran berbasis IT; sebagai nara sumber dan instruktur; sebagai guru pamong, sebagai guru penggerak; dan banyak prestasi yang lain. 
JEMAP: Jurnal Ekonomi, Manajemen, Akuntansi, dan Perpajakan

ISSN: 2622-612X (Media Online) | Vol.4 | No.1 | April 2021

Hasil penelitian ini sesuai dengan pendapat Bakar (2018) yang menyatakan bahwa guru profesional dalam proses pembelajaran akan memiliki keahlian dalam mendidik, mengajar, dan melatih dan menghasilkan sebuah prestasi. Juga sejalan dengan hasil penelitian ini sejalan dengan penelitian dari Andronache (2016), Dewi (2015), Hasan (2017), Sappaile (2017), Hakim (2015), Paida (2018), Sopandi (2019), dan Nurdianti (2017).

\section{Kompetensi Pedagogik Tidak Berpengaruh Terhadap Kinerja Guru}

Pernyataan tersebut mengandung arti kompetensi pedagogik tidak berpengaruh terhadap kinerja guru. Guru mempunyai tingkat kompetensi pedagogis yang tinggi, tetapi juga dibebani dengan kegiatan administratif yang sangat banyak yang menyita waktu sehingga dapat melupakan tugas pokoknya untuk mengajar. Dapat dijelaskan bahwa pada dasarnya guru mempunyai tingkat penguasaan karakteristik siswa yang tinggi, sangat mampu menguasai prinsip-prinsip belajar, sangat mampu mengembangkan kurikulum, tetapi karena guru sangat disibukkan dengan kegiatan administratif seperti pembuatan perangkat pembelajaran yang banyak menyita waktu sehingga tidak memaksimalkan tujuh tugas utama guru. Ketujuh tugas tersebut adalah mendidik, mengajar, membimbing, mengarahkan, melatih, menilai, dan mengevaluasi peserta didik. Dengan kondisi seperti ini maka kinerja guru tidak berjalan maksimal.

Hasil penelitian ini bertentangan dengan pendapat dari Sonmark (2017) yang menyatakan pengetahuan pedagogis mengacu pada hal khusus pengetahuan guru untuk menciptakan lingkungan belajar dan mengajar yang efektif untuk semua siswa, tetapi sejalan dengan penelitian Sumual dkk. (2017) dan Yusnita (2018) yang menyatakan bahwa kompetensi pedagogik mempunyai pengaruh negatif terhadap kinerja guru.

\section{Supervisi Akademik Berpengaruh Positif Dan Signifikan Terhadap Kinerja} Guru

Pernyataan tersebut mengandung arti semakin berkualitas supervisi akademik yang dilakukan kepala sekolah kepada guru maka semakin tinggi kinerja 
guru. Fenomena yang terjadi adalah pembinaan dan penilaian serta pengawasan secara berkesinambungan dan efektif dari kepala sekolah secara langsung juga akan meningkatkan kinerja guru. Hal ini juga akan menciptakan iklim yang kondusif yang mendukung terciptanya peningkatan kinerja guru. Sisi lain arahan dari kepala sekolah dalam hal Rencana Pelaksanaan Pembelajaran (RPP) yang merupakan persiapan guru sebelum mengajar juga sangat mendukung kinerja guru. Dengan persiapan pembelajaran yang matang maka akan menghasilkan proses belajar mengajar akan berkualitas.

Penelitian yang sependapat dengan hal tersebut adalah pengawasan merupakan upaya untuk mendukung profesi pengajaran. Juga didukung dengan penelitian-penelitian terdahulu seperti Veloo (2014), Ramadhan (2017), Purbasari (2015), yang menyatakan supervisi akademik berpengaruh positif dan signifikan terhadap kinerja guru.

\section{Supervisi Akademik Tidak Memoderasi Kompetensi Profesional Terhadap Kinerja Guru}

Pernyataan tersebut mengandung arti supervisi akademik tidak memperkuat maupun memperlemah pengaruh kompetensi profesional terhadap kinerja guru. Supervisi akademik mempunyai nilai yang tinggi terhadap kinerja guru, tetapi tidak dapat memperkuat kinerja guru. Hal ini dapat disebabkan karena kurangnya kompetensi yang dimiliki oleh kepala sekolah dalam melakukan supervisi kepada para guru, juga kesibukan kepala sekolah sehingga tidak mempunyai waktu cukup untuk selalu melaksanakan jadwal supervisi seperti yang telah direncanakan. Maka yang terjadi penilaian kinerja guru tidak bisa terukur dengan jelas sehingga tidak bisa memotivasi guru dalam peningkatan pengelolaan pembelajaran serta pengembangan profesionalisme guru. Berdasarkan pengamatan, kurangnya kompetensi yang dimiliki oleh kepala sekolah disebabkan pendidikan yang belum mencukupi yaitu hanya sarjana (S1) serta kesibukan luar yang luar biasa. Kepala sekolah harus mengikuti Musyawarah Kerja Kepala Sekolah (MKKS), kemudian menerima kunjungan dari pejabat Dinas Propinsi dan pihak lain yang terencana maupun yang tidak terencana. Selain itu kepala sekolah mempunyai tugas sebagai 
perencana program seperti merumuskan, menetapkan, dan mengembangkan visi dan misi sekolah, tujuan sekolah, membuat Rencana Kerja Sekolah (RKS) dan Rencana Kegiatan dan Anggaran Sekolah (RKAS), sebagai pelaksana rencana kerja seperti menyusun KTSP, kalender pendidikan, dan kegiatan; mengelola pendidikan dan tenaga kependidikan; mengelola sarana dan prasarana; mengelola keuangan dan pembiayaan.; mengelola budaya dan lingkungan sekolah; memberdayakan peran masyarakat dan kemitraan sekolah, sebagai pemimpin sekolah.

Fenomena lain dapat juga karena ketidak pedulian terhadap hasil supervisi akademik yang dilakukan oleh kepala sekolah. Artinya hasil penilaian dari supervisi akademik tidak dijadikan umpan balik untuk pembinaan terhadap anak buah sehingga tidak dapat mengoreksi hal-hal yang menjadi kekurangan para guru dalam proses kegiatan belajar serta tidak memberikan penguatan dari kerja para guru yang sudah memenuhi profesionalisme. Hal ini juga dapat disebabkan karena padatnya tugas oleh kepala sekolah sehingga tidak cukup waktu untuk memberikan umpan balik tersebut. Hasil penelitian ini sejalan dengan penelitian yang dilakukan oleh Liana \& Suwarto (2017) yang menyatakan bahwa supervisi akademik tidak memoderasi pengaruh kompetensi profesional terhadap kinerja guru.

\section{Supervisi Akademik Tidak Memoderasi Pengaruh Kompetensi Pedagogik Terhadap Kinerja Guru}

Pernyataan tersebut mengandung arti supervisi akademik tidak mempunyai pengaruh positif atau tidak memperkuat pengaruh kompetensi pedagogik terhadap kinerja guru. Fenomena yang ada adalah adanya ketidak cakapan guru dalam menciptakan lingkungan belajar dan mengajar yang efektif seperti yang dikemukakan Sonmark (2017), bahwa pengetahuan pedagogis mengacu pada hal khusus pengetahuan guru untuk menciptakan lingkungan belajar dan mengajar yang efektif untuk semua.

Selain hal tersebut, dapat terjadi karena kepala sekolah tidak dapat merealisasikan secara maksimal sepuluh peran supervisi akademik yaitu clarifying, listening, reflecting, presenting, clarifying, problem solving, 
encouraging, negotiating, standardizing, dan reflecting. Hal ini dapat terjadi karena kurangnya kompetensi dan pengalaman kepemimpinan kepala sekolah, kesibukan dan banyaknya tugas yang harus diemban oleh kepala sekolah, serta kegiatan dinas luar yang banyak. Juga terjadi karena kurangnya guru-guru tersebut mendapat pelatihan di luar sekolah yang memungkinkan untuk peningkatan kemampuan pedagogik.

\section{SIMPULAN DAN SARAN}

\section{Simpulan}

Berdasarkan hasil analisis data penelitian, maka dapat diambil kesimpulan bahwa kompetensi profesional berpengaruh positif dan signifikan terhadap kinerja guru, kompetensi pedagogik tidak berpengaruh terhadap kinerja guru, supervisi akademik perpengaruh positif dan signifikan terhadap kinerja guru, supervisi akademik tidak memoderasi kompetensi profesional terhadap kinerja guru, dan supervisi akademik tidak memoderasi pengaruh kompetensi pedagogik terhadap kinerja guru.

\section{Saran}

Saran yang dapat disampaikan dari peneliti adalah: Para guru SMA swasta se-Kecamatan Pati perlu mengembangkan dan meningkatkan kompetensi pedagogik, sehingga para guru dapat membagi tugas dan mengatur antara beban administratif dan tugas pokok guru dalam mengajar. Bagi kepala sekolah, perlu mengembangkan dan meningkatkan supervisi akademik untuk memberikan motivasi kepada para guru untuk selalu meningkatkan kinerjanya. Bagi Dinas Pendidikan dan Kebudayaan Provinsi Jawa Tengah, perlu memperhatikan peningkatan tupoksi guru agar dapat mengembangkan kompetensinya dan kepala sekolah dapat memaksimalkan sepuluh peran supervisi akademik.

\section{DAFTAR PUSTAKA}

Aldaihani, S.G.2017.Effect of Prevalent Supervisory Styles on Teaching Performance in Kuwaiti High Schools. Asian Social Science; Vol. 13, No. 4; 2017 ISSN 1911-2017 E-ISSN 1911-2025. 
JEMAP: Jurnal Ekonomi, Manajemen, Akuntansi, dan Perpajakan

ISSN: 2622-612X (Media Online) | Vol.4 | No.1 | April 2021

Andronache, G.2015.Competence and Performance in The Teaching Profession. JEL Classification: I21, L25, M54.a.

Arifin, Z.2013.Menjadi Guru Profesional (Isu dan Tantangan Masa Depan) Menjadi Guru Profesional (Isu Dan Tantangan Masa Depan). Edutech, Tahun 12, Vol.1, No.3.

Bakar, R.2018.The Influence Of Professional Teachers On Padang Vocational School Students' Achievement.

https://doi.org/10.1016/j.kjss.2017.12.017

Barinto.2012.Hubungan Kompetensi Guru dan Supervisi Akademik dengan Kinerja Guru SMP Negeri Se-Kecamatan Precut Sei Tuan. Jurnal Tabularas PPS Unimed. Vol 9 No.2.pp 201-214. ISSN 1693-7732.

Basiya, R. dan Hakim, L.2018.Supervisi Akademik Memoderasi Pengaruh Kompetensi dan Komitmen Organisasi terhadap Kinerja Guru. JBE Vol. 25, (1): 66. ISSN (print): 1412-3126 ISSN (online): 26553066.

Dewi, T. A.2015.Pengaruh Profesionalisme Guru Dan Motivasi Kerja Terhadap Kinerja Guru Ekonomi SMA Se-Kota Malang. ISSN: $2442-9449$ Vol.3. No.1.

Glickman, C. D.1981.Development Supervision Association FPR Supervision And Curriculum Development Nort Washington Street. Virginia Alexandria.

Glickman, C. D., Gordon, S. P., and Ross-Gordon, J.M.2007.Supervision and Instructional Leadership A Development Approach. Seventh Edition. Boston: Perason 
JEMAP: Jurnal Ekonomi, Manajemen, Akuntansi, dan Perpajakan

ISSN: 2622-612X (Media Online) | Vol.4 | No.1 | April 2021

Guerriero, S.2017.Educational Research and Innovation: Pedagogical Knowledge. ISBN 978-92-6427068-8 (print) ISBN 978-92-6427069-5.

Hafni, E.2020.Pengaruh Supervisi Dan Kompetensi Melalui Disiplin Kerja Terhadap Kinerja Guru MAN Se-Kota Medan. ISSN: 2442-7063. ISSN: $2442-6024$

Hakim, A. O.2015.Contribution of Competence Teacher (Pedagogical, Personality, Professional Competence and Social) On the Performance of Learning. Volume $4 \operatorname{ISSN}(e): 2319$ - $1813 \operatorname{ISSN}(p): 2319$ - 1805.

Hasan, M.2017.Pengaruh Kompetensi Profesional Guru Terhadap Kinerja Guru Ekonomi Sekolah Menengah Atas Negeri Di Kabupaten Gowa. Jurnal Economix Vol5 No 2.

Heriswanto.2018.Pengaruh Kompetensi Guru Terhadap Kinerja Guru SMPN I Lambuya Kab. Konawe Melalui Motivasi Kerja Sebagai Variabel Intervening. Volume 3 Nomor 3 Edisi Agustus 2018 (136-152).

Ikhrom.2018.Menyoal Kinerja Guru, Dampak Sertifikasi terhadap Guru. DOI:10.31227/osf.io/3r7v2.

Liana, L. dan Suwarto, D.2017.Supervisi Akademik Memoderasi Pengaruh Kompetensi Profesional Dan Modal Sosial Terhadap Kinerja Guru (Studi Pada SMK Negeri 2 Pati). Vol 1, No 1 (2017).

Mangkunegara, A. P.2009.Evaluasi Kinerja Sumber Daya Manusia. Bandung: Refika Aditama.

Mulyadi, A.2011.Kontribusi Kompetensi Pedagogik dan Iklim Organisasi Terhadap Kinerja Guru. Home Vol 7 No. 2. 
JEMAP: Jurnal Ekonomi, Manajemen, Akuntansi, dan Perpajakan

ISSN: 2622-612X (Media Online) | Vol.4 | No.1 | April 2021

Mulyasa, E.2011.Manajemen dan Kepemimpinan Kepala Sekolah. Jakarta: Bumi Aksara.

Muyiman.2018.The Strategy of Madrasa Ibtidaiya Principal in Human Resource Development for Increasing Teachers' Professional And Academic Competency.DOI: 10.18326/mudarrisa v10i1.127-147.

Ndapaloka, V., Hardyanto, W., dan Prihatin, T.,2016.Pengaruh Supervisi Akademik Pengawas Dan Kepemimpinan Kepala Sekolah Melalui Motivasi Berprestasi Sebagai Mediasi Terhadap Kinerja Guru SMK Negeri Kabupaten Ende.ISSN 2252-7001. EM 5 (1)

Ndebele, C.2013.Prevalent Supervisory Styles in primary Schools in a Remote Rural District in Zimbabwe: Strategies for Reconciling them with Teacher Preferred Supervisory Styles. Stud Tribes Tribals, 11(1): 55-66 (2013).

Novebri, N., Kasman, R., dan Sabandi, A.2018.Relationship Between Pedagogical Competence And Teacher Performance In Public Elementary School. DOI: https://doi.org/10.29210/20181139.

Nurdianti, R. S.2017.Pengaruh Kompetensi Profesional Dan Kompetensi Pedagogik Terhadap Kinerja Guru Ekonomi SMA Negeri Di Kota Bandung. Vol. 18 No. 2, 2017, 177-188 177-188

Paida, A.2018.Pengaruh Kompetensi Pedagogik, Kompetensi Profesional Dan Kepuasan Kerja Terhadap Kinerja Guru Di SMK Negeri 4 Makassar. ISSN: 2621-6477.

Peraturan Pemerintah Nomor 16 Tahun 2007, tentang Standar Kualifikasi Akademik Dan Kompetensi Guru. Jakarta: Depdiknas. 
JEMAP: Jurnal Ekonomi, Manajemen, Akuntansi, dan Perpajakan

ISSN: 2622-612X (Media Online) | Vol.4 | No.1 | April 2021

Peraturan Pemerintah Nomor 41 Tahun 2007, tentang Standar Proses. Jakarta: Depdiknas.

Peraturan Pemerintah Nomor 74 Tahun 2008, tentang Guru. Jakarta: Depdiknas.

Purbasari, M. 2015. Pengaruh Supervisi Akademik terhadap Kinerja Mengajar Guru di Sekolah Dasar. Skripsi. Universitas Negeri Semarang.

Rahman, M.2014.Professional Competenc, Pedagogical Competence and the Performance of Junior High School of Science Teachers. ISSN 2222-1735 Vol 5, No.9.

Ramadhan, A.2017.Pengaruh Pelaksanaan Supervisi Akademik Pengawas Sekolah Dan Supervisi Kepala Sekolah Terhadap Kinerja Guru SMK Negeri Di Kabupaten Majene. ISSN:2460-1497 dan e-ISSN: 2477-3840.

Sappaile, N.2017.Pengaruh Kompetensi Pedagogik, Kompetensi Profesional, dan Sikap Profesi. Guru Tehadap Kinerja Penilaian Guru di Sekolah Dasar Guru Terhadap Kinerja Penilaian Guru di Sekolah Dasar. Jurnal Teknologi Pendidikan.Vol. 19, No. 1.

Sopandi, A.2019.Pengaruh Kompetensi Profesional Dan Kompetensi Kepribadian Terhadap Kinerja Guru. e-ISSN 2621-3389. p-ISSN 2615-3009 Vol. 2, No.2.

Sonmark, K. 2017. Understanding teachers' pedagogical knowledge. Report on An International Pilot Study. OECD Education Working Papers No. 159.

Syahruddin, Andi, E., dan Ede, M, N.2013.Teachers' Pedagogical Competence in School-Based Management: A Case Study in a Public Secondary School at 
JEMAP: Jurnal Ekonomi, Manajemen, Akuntansi, dan Perpajakan

ISSN: 2622-612X (Media Online) | Vol.4 | No.1 | April 2021

Pare-Pare, Indonesia. Journal of Education and Learning. Vol.7(4) pp. 213218.

Tesema, A.2014.The Practices and Challenges of School-Based Supervision in Government Secondary Schools of Kamashi Zone of Benishangul Gumuz Regional. Institute of Education and Professional Development Studies Department of Educational Planning and Management

Undang-Undang Republik Indonesia No. 14 Nomor 2005, tentang Guru dan Dosen. Jakarta: Depdiknas.

Yunos, J. B.M \& Kotirdea., I. Y. 2014. The Processes of Supervisions in Secondary Schools Educational System in Nigeria. Modibbo Adama University of TechnologyYola School of Technology and Science EducationYola Nigeria Faculty of Technical and Vocational Education, Universiti Tun Hussein Onn, Malaysia, 86400, Parit Raja, Batu Pahat, Johor, Malaysia.

Yusriadi.2014.Pengaruh Kompetensi Profesional Dan Iklim Organisasi Terhadap Kinerja Dosen Pada Universitas Malikussaleh. ISSN ISBN 978.602.14708$1-7$.

Veloo, A.2013.The Effects of Clinical Supervision on The Teaching Performance of Secondary School Teachers School of Education and Modern Languages, Universiti Utara Malaysia, 6010 Sintok, Malaysia. 